\title{
Upper Gingival Squamous Cell Carcinoma
}

National Cancer Institute

\section{Source}

National Cancer Institute. Upper Gingival Squamous Cell Carcinoma. NCI Thesaurus.

Code C8173.

A squamous cell carcinoma of the oral cavity that arises from the upper gingiva. 